\title{
Shade Intensity Influences the Nutrient Quality and Digestibility of Southern Deer Browse Leaves
}

\author{
ROBERT M. BLAIR, RENE ALCANIZ, AND AUSTIN HARRELL
}

\begin{abstract}
One deciduous and two broadleaf evergreen species of palatable deer browse were grown under three controlled levels of light reduction: 0,55 , and $92 \%$ shade. Determinations of nutrient composition and dry-matter digestibility were conducted on leaf tissues collected 7 months each year for 2 years. Throughout the year crude protein and the cell-wall constituents, acid-detergent fiber and cellulose, increased as shade deepened. Phosphorus and calcium levels, generally highest under deep shade, showed little difference in content between moderate shade or full sunlight. Reduced light did not affect the acid-detergent lignin content in deciduous dogwood leaves, but, in evergreen yaupon and honeysuckle, lignin content was highest in deep shade. Highly digestible cell solubles and apparent digestible energy content declined as shade increased. Dry-matter digestibility also declined as shade deepened, except the dry matter of dogwood leaves, either in full sun or in moderate shade, did not differ in metabolic usefulness. Seasonally, all leaves were most nutritious and digestible during spring refoliation. In winter, abscised and weathered dogwood leaves afforded little food value to deer, but the quality and digestibility of yaupon and honeysuckle leaves remained relatively high during this stress period.
\end{abstract}

The light climate within a forest stand largely determines, through photosynthesis, the botanical composition, growth, and nutrient quality of understory forages available to deer and other ruminants. Although sunlight is regarded as the most influential environmental parameter, its impact on plant growth and competition is, nevertheless, among the more complex and subtle associations operating within the forest community. Fortunately, light transmission responds to silvicultural treatments, hence, forest managers can manipulate and control the light climate in the understory. With sufficient knowledge concerning response of forages to solar radiation and light intensities associated with the understory of specific forest stands, we can develop silvicultural guidelines for growing quality forages in conjunction with production of wood fiber.

As a contribution toward a better understanding of light and its effect on the metabolic value of forages in southern forests, this paper evaluates variations of nutrient composition and dry matter digestibility of leaf tissues from 3 common and palatable southern deer browses throughout the year under 3 different intensities of shade. Species selected were flowering dogwood (Cornus florida), a small deciduous tree; yaupon (Ilex vomitoria), a broadleaf evergreen shrub; and Japanese honeysuckle (Lonicera japonica), a vine that is generally evergreen in the Gulf Coastal Plain. Only leaves were selected for evaluation since they are a major dietary constituent at all seasons for southern decr, and are considerably more important than twigs (Harlow and Hooper 1972).

\footnotetext{
Authors are research ecologist and research technician, Wildlife Habitat and Silvicultural Laboratory maintained at Nacogdoches, Texas 75962 , by the Southern Forest Experiment Station, Forest Service, USDA, in cooperation with the School of Forestry, Stephen F. Austin State University; and associate professor of agricultural chemistry, Feed and Fertilizer Laboratory, Louisiana Agricultural Experiment Station, Louisiana State University, Baton Rouge 70893.
}

Shade tolerance of dogwood, yaupon, and honeysuckle was assumed to be reasonably similar, with dogwood being most tolerant. Differences in species tolerance are largely related to differences in the ability of their photosynthetic apparatus to adapt to low light intensity (Kramer and Kozlowski 1979). It is reasonable to assume that these differences, if sufficiently large, might influence the nutrient composition of species at different light levels.

\section{Study Area and Methods}

The research was conducted from 1974 through 1977 on the Stephen F. Austin Experimental Forest near Nacogdoches, Texas. The area is within the loblolly-shortleaf pine forest type. Primary overstory species in this type are loblolly pine (Pinus taeda) and shortleaf pine (Pinus echinata) associated with assorted hardward species. Stands characteristically contain a multi-tiered midstory of pines, hardwoods, and shrubs. Such a stand structure generally results in heavy shading with little sunlight reaching the forest floor.

Soil of the open and relatively flat study site is deep, well-drained Ruston fine sandy loam with a fine sandy clay loam subsoil. It is acid in reaction throughout the profile with a moderate amount of organic matter and natural plant nutrients. Water storage capacity is high. The soil is uniform throughout the study area.

Summer climate is hot and humid while winters are generally mild. The mean frost free season is about 243 days from midMarch to mid-November. An average annual precipitation of 122 $\mathrm{cm}$ is generally well distributed throughout the year. Spring growth of woody perennials begins in late March or early April and twig elongation and tissue maturation are nearly completed on most species by early summer (Halls and Alcaniz 1965). Growth activity is common on some broadleaf evergreens during intermittent warm periods in winter.

The study site was plowed and leveled to reduce'competing vegetation, then enclosed by an outrigger-type fence to exclude grazing and browsing animals. Twelve $7(\mathrm{~W}) \times 27(\mathrm{~L}) \mathrm{m}$ plots were established in a rectangular layout with plots separated from one another by a $15-\mathrm{m}$ buffer.

\section{Shade Intensities}

Shade levels of 0,55 , and $92 \%$ were randomly assigned to treatment plots. Each intensity was replicated 4 times in a completely randomized design. To accomplish shade conditions, Propa-lite polypropylene fabric (Chicopee Manufacturing Company, Cornelia, Ga.)', woven to provide the prescribed reductions in light, was placed over a $7(\mathrm{~W}) \times 27(\mathrm{~L}) \times 2.5(\mathrm{H}) \mathrm{m}$ wooden frame encompassing each plot. The bottom $0.3 \mathrm{~m}$ on the sides and the top $1 \mathrm{~m}$ on the end walls were not covered by fabric to facilitate air movement. Light entry at the upper end-wall openings was controlled by a fabric covered overhang. Shade fabric was placed over

\footnotetext{
The use of the corporation name is for the information and convenience of the reader. Such use does not constitute an official endorsement or approval by the U.S. Department of Agriculture of any product or service to the exclusion of others which may be
} suitable. 
the plots immediately before outplanting study species.

\section{Plant Species}

Flowering dogwood and yaupon plants were 2-year-old container-grown nursery stock. Japanese honeysuckle stock was young rooted leaders lifted from an open area adjacent to the study plots.

One 16-plant row of each species was outplanted on each treatment plot in February 1974. Row assignments were random. Plants were spaced $1.5 \mathrm{~m}$ within a row with $2.4 \mathrm{~m}$ between rows. The long axes of plots were oriented northeast by southwest to insure that all plants within a treatment would receive about equal exposure to solar radiation. Plant shading between rows was minimal. Honeysuckle growth was supported on $1 \mathrm{~m}$ high woven-wire trellises.

To eliminate gross differences in soil moisture between treatments and to maintain sufficient soil moisture during extended dry periods, plots were watered, as needed, by oscillating sprinklers. More frequent watering was necessary where shade was absent or moderately intense than where shade was heavy. Near each end of individual plots, 2 gypsum soil blocks were buried, one at $15 \mathrm{~cm}$ and another at $46 \mathrm{~cm}$, to monitor soil moisture. To ascertain water needs blocks were checked periodically with a Bouyoucos soil moisture meter.

\section{Collection of Plant Tissues}

Beginning in the spring of 1976 , after plants were grown 2 years under their assigned shade regime, leaf samples were collected 7 times yearly for 2 years: at mid-month in April and May, the spring period of rapid plant growth; in June, July, August, and September, the early through late summer period of heat stress on both plants and deer; and in December, during general plant dormancy and a period of minimal forage availability and nutrient stress for deer.

Current leaves from the terminal $10 \mathrm{~cm}$ or less of dogwood and yaupon twig growth and $20 \mathrm{~cm}$ or less of honeysuckle leaders were collected for analytical determinations. Sampling only from terminal twig segments minimized the effects of mutual leaf shading. All samples were collected between 10:00 a.m. and 2:00 p.m. to minimize diurnal fluctuation in sugar content of the cell sap.

At each collection date, a leaf sample was removed from one randomly selected plant within a species row; therefore, individual plants were sampled only once during the year. Dogwood and yaupon samples were limited to the upper one-half of the plant canopy. Honeysuckle leaves were removed from the entire plant, excluding ground runners.

For a winter sample of flowering dogwood, crowns of selected plants were enveloped in a fine nylon net just prior to leaf fall. After abscission, leaves were spread out to weather in shallow wire baskets placed $15 \mathrm{~cm}$ above ground next to the sample tree. Leaf tissue for the winter sample necessarily came from the entire crown.

Except for the winter collection, each leaf sample was placed in a moisture-tight container and immediately stored on ice to retard enzymatic degradation. Samples from each treatment plot were transported to the laboratory, weighed fresh, and then dried to constant weight in a forced-draft oven at $60^{\circ} \mathrm{C}$. At the spring date, an additional sample of each species was collected and dried, first at $60^{\circ} \mathrm{C}$ and then at $100^{\circ} \mathrm{C}$. Dry matter difference between temperatures was used to correct all samples to an oven-dry base. Dried tissues were ground to pass through a $1-\mathrm{mm}$ Wiley mill screen and were temporarily stored in a freezer until analytical determinations could be made.

Phenological data were collected from study plants throughout the year to evaluate any differences in seasonal development associated with reduced levels of light and the influence this might have on nutrient chemistry and dry-matter digestibility. Earlier research has repeatedly shown that seasonal variations in nutrient chemistry and dry-matter digestibility of southern forages are directly related to the stage of tissue growth and maturation (Blair and Halls 1968, Blair and Epps 1969, Short et al. 1972). Studies by
McEwen and Dietz (1965) and Wolters (1974) found that shade can retard phenological development of herbaceous species. To minimize retarding effects that shade might have on the development and chemistry of browse, leaf samples collected each monthly period were taken first from plants in the open, next from those in $55 \%$ shade, and last from those under $92 \%$ shade. This collection sequence allowed added days of phenological development for shaded plants.

\section{Nutrient and Digestibility Analyses}

Leaf tissues were analyzed for crude protein, phosphorus, and calcium (AOAC 1965), neutral-detergent fiber or cell-wall constituents (CWC), acid-detergent fiber (ADF), acid-detergent lignin (ADL), and silica (Goering and Van Soest 1970). Neutraldetergent solubles or cell solubles (CS) were estimated as the difference between total dry matter and $\mathrm{CWC}$, hemicellulose as the difference between CWC and ADF, and cellulose as the difference between ADF and ADL. In addition, caloric values, expressed as gross energy (GE), were assayed by oxygen bomb calorimetry and converted to apparent digestible energy (ADE) using the regression $\mathrm{Y}=-0.713+0.991 \mathrm{X}$, where $\mathrm{Y}=\% \mathrm{ADE}$ and $\mathrm{X}=\%$ dry-matter digestibility (Robbins et al. 1975). ADE was expressed as a caloric value by the equation, $\mathrm{cal} / \mathrm{gm}=\mathrm{GE} \times \% \mathrm{ADE} / 100$.

In vitro dry-matter digestibility was determined by the 2 -stage method of Tilley and Terry (1963) as modified by Palmer et al. (1976) and Carlile (1978). The source of inoculum for in vitro digestions was a rumen-fistulated Hereford steer maintained on a 50:50 concentrate:roughage diet. In vivo dry-matter digestibility (IVDMD) values for deer were estimated from in vitro determinations using the prediction equation $\mathrm{Y}=\mathrm{a}+\mathrm{bX}$, where $\mathrm{Y}=\%$ in vivo digestibility and $\mathrm{X}=\%$ in vitro digestibility. "Standard substrates of known in vivo deer digestibilities were run simultaneously with each set of in vitro samples of unknown value as described by Palmer et al. (1976) and Carlile (1978). Results were then used to calculate an in vivo digestibility prediction equation for each trial.

Gross energy and digestibility determinations were conducted by the Department of Fisheries and Wildlife Sciences, Virginia Polytechnic Institute and State University, Blacksburg; all other chemical analyses were by the Feed and Fertilizer Laboratory, Louisiana Agricultural Experiment Station, Louisiana State University, Baton Rouge.

\section{Environmental Measurements}

From mid-March through mid-November of sampling years, maximum, minimum, and ambient air temperatures, soil temperature, and relative humidity were taken biweekly on 1 random plot for each shade regime. Air temperatures were determined at $76 \mathrm{~cm}$ and relative humidity at about $122 \mathrm{~cm}$ above ground at the plot center. Soil temperature was taken by a probe thermometer inserted $8 \mathrm{~cm}$ below the soil surface at 2 points near the plot center.

\section{Statistical Analysis}

Chemical constituent and dry-matter digestibility data were subjected to variance analyses to evaluate differences caused by light reduction, changes during phenological development, and variations in species response. Differences among means were defined by Duncan's multiple range test. All testing was at the 0.05 probability level.

\section{Results}

\section{Environment and Morphological Development}

Other than reduced levels of light, the microclimate did not differ widely between treatments. At mid-day, relative humidity averaged less than 5 percentage units higher on shaded plots, particularly those under heavy shade, than on open plots. As expected, both maximum and ambient air temperatures were inversely related to shade intensity, while minimum temperature was directly related. The average differential, however, for maxi- 
mum and minimum temperatures between the warmest and coolest treatments did not exceed $3.5^{\circ} \mathrm{C}$, while the average differential for ambient temperature did not exceed $2^{\circ} \mathrm{C}$.

Surface soils were somewhat cooler beneath shade. Soil temperature averaged $3.6^{\circ} \mathrm{C}$ cooler under moderate shade and $4.8^{\circ} \mathrm{C}$ cooler under heavy shade than in the open. Moisture was retained by soils following rain or manual watering in direct relation to shade intensity.

Shading had only a minimal effect on phenological development of all species. Twig elongation and refoliation began in the open and under $55 \%$ shade at about the same time in late March, but was initiated 5 to 7 days later under $92 \%$ shade. Twig elongation was nearly completed by late May on plants in the open and under moderate shade, but growth continued an additional 7 to 10 days under heavy shade.

In late autumn, dogwoods growing under $55 \%$ shade retained at least half their leaves up to 2 weeks after leaves abscised from open-grown plants. In deep shade, about half of the leaves were retained for $31 / 2$ weeks longer than in the open; some green leaves were still on the plants in midwinter.

Plant growth, canopy form, and vigor differed noticeably between light intensities. Plants of all species in moderate shade were noticeably more robust in form and appeared more vigorous than those in deep shade or in full sunlight. Open-grown plants of dogwood and yaupon were several fold smaller in size and had considerably smaller leaves than shaded plants. In deep shade, dogwood and yaupon plants were comparable in size to those in moderate shade. Although crowns were not as compact, leaf density was noticeably lower, and leaf blades were larger.

Honeysuckle vigor appeared to be poorest in deep shade where plants showed obvious signs of stress. Even though new leaders were initiated each spring, a portion of the current leaves would yellow and abscise as the growth flush matured. Leaders would then die back several centimeters. Apparently the photosynthetic machinery of honeysuckle leaves could not adapt to the low level of light. Plants were unable to produce sufficient photosynthate for growth and maintenance; hence, above-ground biomass progressively dwindled.

\section{Nutrient Quality}

Light reduction significantly influenced the chemical composition of leaf tissues throughout the year. Further, these relationships were generally consistent at each sampling period. Nutrient quality of leaves changed as seasons progressed, particularly from spring to summer, but these changes were largely a product of plant growth and tissue maturation. We feel, therefore, that differences between light regimes in the chemical composition of leaves, as shown in Table 1, were caused primarily by light reduction and not by differences in the stage of morphological development.

\section{Dry Matter}

Throughout the year, leaf dry matter of all species tended to decline as shaded deepened (Table 1), although honeysuckle was the only species where the inverse relationship was significant between all treatments. While dry matter content of dogwood and yaupon varied little between leaves in full sunlight and those in $55 \%$ shade, the content was significantly lower in tissues grown under $\mathbf{9 2} \%$ shade. Similar responses in the dry matter content of shadeand open-grown grasses were reported by Burton et al. (1959), Deinum (1966), Myhr and Saebo (1969), and Mayland and Grunes (1974).

Seasonally, leaf dry matter under all shade regimes was characteristically lowest during spring refoliation. As tissues progressively matured, the dry matter content of leaves had increased by mid-May to levels that were maintained from summer through winter. In December samples, the abscised leaves of dogwood were exceptionally high in dry matter due to air drying.

\section{Crude Protein}

At all seasons, crude protein increased in leaves of all species as shade deepened (Table 1). Differences were substantial. For exam- ple, during the period of most rapid growth in April, average crude protein content of tissues was $31 \%$ higher in medium shade and $70 \%$ higher in deep shade than in the open. These differences increased as leaves matured so that from May to December protein averaged $51 \%$ higher in moderate shade and $94 \%$ higher in deep shade than in full sunlight. Differences in leaves grown in various shade intensities followed results of earlier research on herbaceous and woody species. Cook and Harris (1950), Burton et al. (1959), Vallentine and Young (1959), Deinum (1966), Myhr and Saebo (1969), Wolters (1973, 1974), and Mayland and Grunes (1974) found that nitrogen or crude protein $(\mathrm{N} \times 6.25)$ content was higher in shaded plants than those grown in full sunlight. Halls and Epps (1969), however, reported lower crude protein in browse leaves below a forest canopy as opposed to those in the open, while McEwan and Dietz (1965) found highly variable responses between plants in the open and beneath a canopy.

Seasonal trends in leaf protein were similar over all species and shade regimes. Levels were highest in rapidly growing and more succulent April tissues, followed by a rather abrupt and significant decline by mid-May as leaves matured. It is interesting that the magnitude of protein decline that accompanied tissue maturation was less under shade; an average $29 \%$ drop in open-grown leaves was recorded, as compared to $23 \%$ in moderate shade and $19 \%$ in deep shade.

Throughout summer, crude protein varied little in mature leaf tissues. Prior to the advent of cold weather and loss of leaves from deciduous species, a considerable portion of the nitrogen in leaves is translocated back into the twigs (Kramer and Kozlowski 1979). Hence, the abscised and weathered leaves of dogwood were a very poor source of protein during the winter stress period. The level of protein in yaupon leaves did not vary significantly with the advent of winter but the level in honeysuckle leaves increased. New leaf growth on honeysuckle was stimulated by warming trends in winter and the presence of new tissues probably accounted for the higher levels of winter protein.

Within each respective shade regime dogwood leaves were generally a poorer source of protein yearlong than either yaupon or honeysuckle. Such difference is particularly important in winter when nutritious forages are at a low ebb. During this period, leaves of broadleaf evergreens can be a crucial source of protein for stressed herbivores.

\section{Phosphorus and Calcium}

Leaves of all species grown in $92 \%$ shade were significantly higher in phosphorus throughout the year than those in full sunlight, except during winter when the percent of phosphorus in weathered dogwood leaves was unaffected by the light climate (Table 1). From spring through summer, phosphorus levels in dogwood and yaupon leaves growing in moderate shade generally did not differ from those in the open, whereas levels in honeysuckle tissues in moderate shade did not differ from those in deep shade.

Seasonally, phosphorus levels under all shade regimes were highest in the new April tissues. After a sharp decline by mid-May, phosphorus levels were fairly constant throughout the year. Winter leaves of dogwood contained the least phosphorus, probably resulting from partial translocation of the mineral back into twigs prior to leaf abscission. Honeysuckle leaves appeared to be a better source of phosphorus throughout the year than either dogwood or yaupon.

Calcium was significantly higher throughout the year in deep shaded leaves than those growing in full sunlight or in moderate shade. The content did not differ statistically between leaves in the open and those in moderate shade.

Previous research findings varied somewhat on the influence of light or phosphorus and calcium. Burton et al. (1959), McEwen and Dietz (1965), and Wolters $(1973,1974)$ reported that phosphorus and/or calcium levels were higher in shaded forage, while Halls and Epps (1969) found that leaves beneath a forest canopy were lower in phosphorus but higher in calcium than those in the open. Mayland and Grunes (1974) concluded that there was no difference 
Table 1. Chemical composition and dry-matter digestibility of leaf tissues grown under three levels of shade in east Texas.' Means of leaves collected in 1976 and 1977.

\begin{tabular}{|c|c|c|c|c|c|c|c|c|c|c|c|c|}
\hline species & - shade & Apr. & may & & June & July & Aug. & & sept. & & Dec. & \\
\hline & \multicolumn{12}{|c|}{ Dry Matter ${ }^{2}$} \\
\hline rlowering dogwood & $\begin{array}{r}0 \\
55 \\
92\end{array}$ & $\begin{array}{l}34 a \\
32 \\
22\end{array}$ & $\begin{array}{l}10: \\
37: \\
26:\end{array}$ & & $\begin{array}{ll}39 & a \\
38 & a \\
28 & b\end{array}$ & $\begin{array}{ll}41 & a \\
40 & a \\
28 & b\end{array}$ & $\begin{array}{ll}42 & a \\
41 & a \\
32 & b\end{array}$ & & $\begin{array}{ll}42 & a \\
40 & a \\
32 & b\end{array}$ & & $\begin{array}{ll}81 & a \\
78 & a \\
70 & b\end{array}$ & \\
\hline Yaupon & $\begin{array}{r}0 \\
55 \\
92\end{array}$ & $\begin{array}{ll}33 & a \\
30 & a \\
23 & b\end{array}$ & $\begin{array}{l}420 \\
410 \\
31\end{array}$ & $\begin{array}{l}a \\
b\end{array}$ & $\begin{array}{ll}44 & a \\
41 & a \\
33 & b\end{array}$ & $\begin{array}{ll}43 & a \\
41 & a \\
33 & b\end{array}$ & $\begin{array}{ll}46 & a \\
44 & a \\
35 & b\end{array}$ & $\begin{array}{l}a \\
b\end{array}$ & $\begin{array}{ll}47 & a \\
44 & a \\
33 & b\end{array}$ & & $\begin{array}{ll}46 & a \\
46 & a \\
36 & b\end{array}$ & $\begin{array}{l}a \\
a \\
b\end{array}$ \\
\hline \multirow[t]{2}{*}{ Japanese honeysuck le } & $\begin{array}{r}0 \\
55 \\
92\end{array}$ & $\begin{array}{ll}30 & \mathrm{a} \\
23 & \mathrm{~b} \\
17 & \mathrm{c}\end{array}$ & $\begin{array}{ll}35 & a \\
26 & b \\
19 & c\end{array}$ & $\begin{array}{l}\mathbf{a} \\
\mathbf{b} \\
\mathbf{c}\end{array}$ & $\begin{array}{ll}36 & a \\
27 & b \\
21 & c\end{array}$ & $\begin{array}{ll}37 & a \\
27 & b \\
22 & c\end{array}$ & $\begin{array}{ll}37 & \mathrm{a} \\
27 & \mathrm{~b} \\
23 & \mathrm{c}\end{array}$ & $\begin{array}{l}a \\
b \\
c\end{array}$ & $\begin{array}{ll}38 & a \\
27 & b \\
22 & c\end{array}$ & $\begin{array}{l}a \\
b \\
c\end{array}$ & $\begin{array}{ll}35 & a \\
27 & b \\
22 & c\end{array}$ & $\begin{array}{l}a \\
b \\
c\end{array}$ \\
\hline & \multicolumn{12}{|c|}{ Crude Protein ${ }^{3}$} \\
\hline Flowering dogwood & $\begin{array}{r}0 \\
55 \\
92\end{array}$ & $\begin{array}{ll}12 & c \\
14 & b \\
22 & a\end{array}$ & $\begin{array}{r}8 \\
11 \\
18\end{array}$ & $\begin{array}{l}c \\
b \\
a\end{array}$ & $\begin{array}{rl}8 & c \\
12 & b \\
16 & a\end{array}$ & $\begin{array}{rl}7 & c \\
10 & b \\
13 & a\end{array}$ & $\begin{array}{l}78 \\
11 \\
13\end{array}$ & $\begin{array}{l}c \\
b \\
a\end{array}$ & $\begin{array}{rl}7 & 0 \\
10 & 6 \\
13 & 0\end{array}$ & $\begin{array}{l}c \\
b \\
a\end{array}$ & $\begin{array}{l}4 \\
5 \\
8\end{array}$ & $\begin{array}{l}\mathbf{c} \\
\mathbf{b} \\
\mathbf{a}\end{array}$ \\
\hline Yaupon & $\begin{array}{r}0 \\
55 \\
92\end{array}$ & $\begin{array}{ll}15 & c \\
18 & b \\
24 & \end{array}$ & $\begin{array}{l}10 \\
14 \\
19\end{array}$ & $\begin{array}{l}c \\
b \\
a\end{array}$ & $\begin{array}{rl}9 & c \\
13 & b \\
19 & a\end{array}$ & $\begin{array}{rl}9 & c \\
13 & b \\
19 & a\end{array}$ & $\begin{array}{r}8 \\
12 \\
17\end{array}$ & $\begin{array}{l}c \\
b \\
a\end{array}$ & $\begin{array}{r}80 \\
145 \\
18\end{array}$ & $\begin{array}{l}c \\
b \\
a\end{array}$ & $\begin{array}{r}9 \\
12 \\
16\end{array}$ & $\begin{array}{l}c \\
b \\
a\end{array}$ \\
\hline \multirow[t]{2}{*}{ Japanese honeysuck le } & $\begin{array}{r}0 \\
55 \\
92\end{array}$ & $\begin{array}{ll}12 & c \\
19 & b \\
21 & a\end{array}$ & $\begin{array}{l}10 \\
15 \\
18\end{array}$ & $\begin{array}{l}c \\
b \\
a\end{array}$ & $\begin{array}{rl}9 & c \\
15 & b \\
17 & a\end{array}$ & $\begin{array}{r}9 \mathrm{c} \\
14 \mathrm{~b} \\
16 \mathrm{a}\end{array}$ & $\begin{array}{r}9 \\
15 \\
17\end{array}$ & $\begin{array}{l}c \\
b \\
a\end{array}$ & $\begin{array}{l}8 \\
15 \\
18\end{array}$ & $\begin{array}{l}c \\
b \\
a\end{array}$ & $\begin{array}{l}10 \\
17 \\
18\end{array}$ & $\begin{array}{l}c \\
b \\
a\end{array}$ \\
\hline & \multicolumn{12}{|c|}{ Phosphorus 3} \\
\hline Flowering dogwood & $\begin{array}{r}0 \\
55 \\
92\end{array}$ & $\begin{array}{ll}.18 & b \\
.21 & b \\
.30 & a\end{array}$ & $\begin{array}{l}.12 \\
.11 \\
.19\end{array}$ & $\begin{array}{l}b \\
b \\
a\end{array}$ & $\begin{array}{ll}.09 & \mathrm{~b} \\
.12 & \mathrm{~b} \\
.17 & \mathrm{a}\end{array}$ & $\begin{array}{ll}.09 & \mathrm{~b} \\
.11 & \mathrm{~b} \\
.15 & \mathrm{a}\end{array}$ & $\begin{array}{l}.11 \\
.13 \\
.16\end{array}$ & $\begin{array}{l}b \\
a b \\
a\end{array}$ & $\begin{array}{l}.08 \\
.11 \\
.14\end{array}$ & $\begin{array}{l}b \\
b \\
a\end{array}$ & $\begin{array}{l}.05 \\
.09 \\
.08\end{array}$ & a \\
\hline Yaupon & $\begin{array}{r}0 \\
55 \\
92\end{array}$ & $\begin{array}{l}.24 b \\
.24 b \\
.32 \mathrm{~b}\end{array}$ & $\begin{array}{l}.11 \\
.14 \\
.18\end{array}$ & $\begin{array}{l}b \\
b \\
a\end{array}$ & $\begin{array}{l}.10 \mathrm{~b} \\
.12 \mathrm{~b} \\
.15 \mathrm{a}\end{array}$ & $\begin{array}{l}.10 \mathrm{~b} \\
.12 \mathrm{~b} \\
.14 \mathrm{a}\end{array}$ & $\begin{array}{l}.09 \\
.11 \\
.14\end{array}$ & $\begin{array}{l}b \\
b \\
a\end{array}$ & $\begin{array}{l}.08 \\
.11 \\
.15\end{array}$ & $\begin{array}{l}b \\
b \\
a\end{array}$ & $\begin{array}{l}.11 \\
.13 \\
.15\end{array}$ & $\begin{array}{l}c \\
b \\
a\end{array}$ \\
\hline \multirow[t]{2}{*}{ Japanese honeysuck le } & $\begin{array}{r}0 \\
55 \\
92\end{array}$ & $\begin{array}{l}.21 \mathrm{~b} \\
.34 a \\
.34 a\end{array}$ & $\begin{array}{l}.14 \\
.28 \\
.26\end{array}$ & $\begin{array}{l}b \\
a \\
a\end{array}$ & $\begin{array}{l}.12 \mathrm{~b} \\
.25 \mathrm{a} \\
.26 \mathrm{a}\end{array}$ & $\begin{array}{l}.14 b \\
.26 a \\
.29 a\end{array}$ & $\begin{array}{l}.15 \\
.24 \\
.29\end{array}$ & $\begin{array}{l}b \\
a \\
a\end{array}$ & $\begin{array}{l}.121 \\
.24 \\
.30\end{array}$ & b & $\begin{array}{l}.13 \\
.22 \\
.29\end{array}$ & $\begin{array}{l}c \\
b \\
a\end{array}$ \\
\hline & \multicolumn{12}{|c|}{ Calcium $^{3}$} \\
\hline Flowering dogwood & $\begin{array}{r}0 \\
55 \\
92\end{array}$ & $\begin{array}{ll}1.80 & \mathrm{~b} \\
1.73 & \mathrm{~b} \\
3.17 & \mathrm{a}\end{array}$ & $\begin{array}{l}2.13 \\
2.18 \\
3.49\end{array}$ & $\begin{array}{l}b \\
b \\
a\end{array}$ & $\begin{array}{ll}2.14 & b \\
2.27 & b \\
3.57 & a\end{array}$ & $\begin{array}{l}2.12 b \\
2.29 b \\
3.60 a\end{array}$ & $\begin{array}{l}2.16 \\
2.30 \\
3.60\end{array}$ & $\begin{array}{l}b \\
b \\
a\end{array}$ & $\begin{array}{l}2.15 \\
2.31 \\
3.57\end{array}$ & $\begin{array}{l}b \\
b \\
a\end{array}$ & $\begin{array}{l}2.24 \\
2.33 \\
3.73\end{array}$ & $\begin{array}{l}b \\
b \\
a\end{array}$ \\
\hline Yaupon & $\begin{array}{r}0 \\
55 \\
92\end{array}$ & $\begin{array}{ll}.33 & \mathrm{~b} \\
.35 & \mathrm{~b} \\
.48 \mathrm{a}\end{array}$ & $\begin{array}{l}.42 \\
.39 \\
.54\end{array}$ & $\begin{array}{l}b \\
b \\
a\end{array}$ & $\begin{array}{l}.44 \mathrm{~b} \\
.41 \mathrm{~b} \\
.59 \mathrm{a}\end{array}$ & 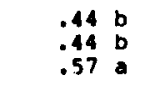 & $\begin{array}{l}.40 \\
.45 \\
.59\end{array}$ & $\begin{array}{l}b \\
b \\
a\end{array}$ & $\begin{array}{l}.47 \\
.47 \\
.61\end{array}$ & $\begin{array}{l}b \\
b \\
a\end{array}$ & $\begin{array}{l}.48 \\
.50 \\
.62\end{array}$ & $\begin{array}{l}b \\
b \\
a\end{array}$ \\
\hline Japanese honeysuckle & $\begin{array}{r}0 \\
55 \\
92\end{array}$ & $\begin{array}{rl}.65 & b \\
.78 & b \\
1.18 & a\end{array}$ & $\begin{array}{r}.84 \\
.86 \\
1.24\end{array}$ & $\begin{array}{l}b \\
b \\
a\end{array}$ & $\begin{array}{r}.95 \mathrm{~b} \\
.88 \mathrm{~b} \\
1.27 \mathrm{a}\end{array}$ & $\begin{array}{r}.94 \mathrm{~b} \\
.86 \mathrm{~b} \\
1.26 \mathrm{a}\end{array}$ & $\begin{array}{r}1.01 \\
.91 \\
1.25\end{array}$ & $\begin{array}{l}b \\
b \\
a\end{array}$ & $\begin{array}{r}1.04 \mathrm{~b} \\
.96 \mathrm{~b} \\
1.25 \mathrm{z}\end{array}$ & $\begin{array}{l}b \\
b \\
a\end{array}$ & $\begin{array}{r}1.06 \\
.99 \\
1.28\end{array}$ & $\begin{array}{l}b \\
b \\
a\end{array}$ \\
\hline
\end{tabular}

Flowering dogwood

Yaupon

Japanese honeysuck le

Flowering dogwood

Yaupon

Japanese honeysuck le
0
55
92

0
55
92

0
55
92

0
55
92

$\begin{array}{ll}0 & 26\end{array}$

$\begin{array}{rl}0 & 26 \mathrm{c} \\ 55 & 32 \mathrm{~b} \\ 92 & 36\end{array}$

72 a

18

27 a

28 c

33 b
82 a 82 a

$78 \mathrm{~b} \quad 77 \mathrm{~b}$

$67 \mathrm{~b}$

74 a

$68 \mathrm{~b}$

$64 \mathrm{c}$
$72 \mathrm{c}$

$70 \mathrm{a}$

$61 \mathrm{c}$

73 a

$62 \mathrm{c}$

$18 \mathrm{C}$

23 b

$30 \mathrm{c}$

$35 \mathrm{~b}$

$27 \mathrm{c}$

$33 \mathrm{~b}$
Cell solubles 3

$\begin{array}{lll}81 & a & 79 \\ 76 & b & 75 \\ 72 & c & 70 \\ 66 & a & 63 \\ 60 & b & 59 \\ 57 & c & 55 \\ 67 & a & 65 \\ 63 & b & 61 \\ 59 & c & 57\end{array}$

Cel1 wall Const 1 tuents ${ }^{3}$

$\begin{array}{llllll}19 \mathrm{c} & 21 \mathrm{c} & 19 \mathrm{c} & 21 \mathrm{c} & 31 \mathrm{c} \\ 24 \mathrm{~b} & 25 \mathrm{~b} & 23 \mathrm{~b} & 26 \mathrm{~b} & 38 \mathrm{~b} \\ 28 \mathrm{a} & 30 \mathrm{a} & 27 \mathrm{a} & 30 \mathrm{a} & 44 \mathrm{a} \\ 34 \mathrm{c} & 37 \mathrm{c} & 33 \mathrm{c} & 34 \mathrm{c} & 32 \mathrm{c} \\ 40 \mathrm{~b} & 41 \mathrm{~b} & 38 \mathrm{~b} & 38 \mathrm{~b} & 37 \mathrm{~b} \\ 43 \mathrm{a} & 43 \mathrm{a} & 44 \mathrm{a} & 45 \mathrm{a} & 43 \mathrm{a} \\ 33 \mathrm{c} & 35 \mathrm{c} & 34 \mathrm{c} & 32 \mathrm{c} & 29 \mathrm{c} \\ 37 \mathrm{~b} & 39 \mathrm{~b} & 39 \mathrm{~b} & 36 \mathrm{~b} & 34 \mathrm{~b} \\ 41 \mathrm{a} & 43 \mathrm{a} & 44 \mathrm{a} & 44 \mathrm{a} & 42 \mathrm{a}\end{array}$


Table 1. (continued)

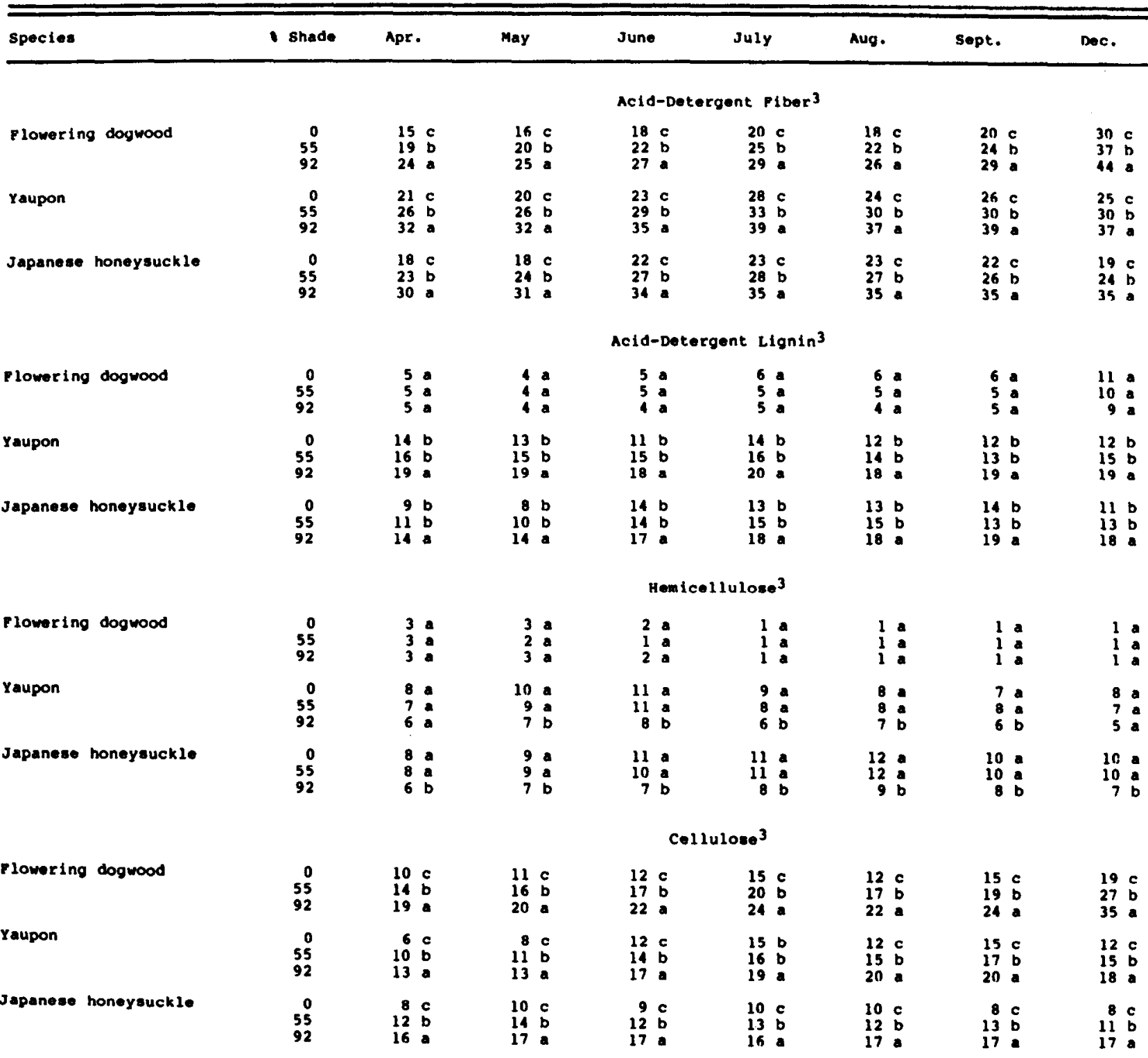

Flowering dogwood

Yaupon

Japanese honeyauck le

Apparent Digestible Energy

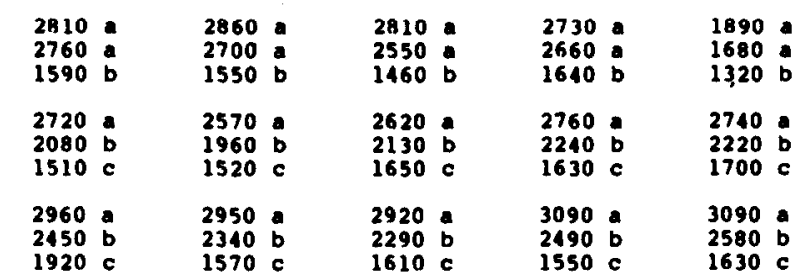

In Vivo Dry-Matter Digestibility 3

Plowering dogwood

Yaupon

Japenese honeyeuck 20

$1730 \mathrm{~b} \quad 1790 \mathrm{~b}$

$\begin{array}{rl}0 & 3000 \mathrm{a} \\ 55 & 2550 \mathrm{~b} \\ 92 & 1910 \mathrm{c}\end{array}$

2960 a

2340 b

3130 a 3150

$\begin{array}{rl}0 & 3130 \\ 55 & 2640 \mathrm{~b} \\ 92 & 1760 \mathrm{c}\end{array}$

$3150 \mathrm{a}$
$2700 \mathrm{~b}$
$1900 \mathrm{c}$
Acid-Detergent Piber 3

1 a

a

$2 \mathrm{~b}$

9 .

$1 b$

$13 \mathrm{~b}$

9 c 5 a

$2 \mathrm{c}$

$15 \mathrm{~b}$

$8 \mathrm{c}$

17 a 
in the phosphorus content of grasses between open and shaded sites, but they reported that calcium levels were higher in shade. Cook and Harris (1950) and Vallentine and Young (1959) reported that phosphorus was higher in shade while calcium did not differ.

Calcium levels were lowest in new leaves in April regardless of light intensity. However, the content increased significantly in all species as leaves matured by mid-May. Generally, little seasonal variation occurred thereafter. Dogwood leaves were a substantially better source of calcium in all months and light regimes than yaupon and honeysuckle tissucs. Yaupon contained the least calcium.

\section{Cell Solubles}

The cell-soluble fraction (cell contents), which consists of lipids, starch, sugars, organic acids, nonprotein nitrogen, pectins, soluble protein, and other water soluble matter, is not only the largest plant fraction in leaf tissues but is also readily digested by ruminants. All year, cell solubles were highest in open-grown leaves of all species (Table 1), with levels declining significantly as shade deepened. For example, leaves in the open averaged $7 \%$ more cell solubles than those under moderate shade and $16 \%$ more than those in deep shade. These trends are similar to trends reported by Burton et al. (1959) where shade reduced total available carbohydrates in grasses. Also, McEwen and Dietz (1965) and Wolters (1973, 1974) found that nitrogen-free extracts, which represent available carbohydrates, were lower in shaded than in open-grown forage.

Cell soluble levels, especially in dogwood leaves, generally varied little during spring and summer. In winter, the contents were significantly lower in weathered dogwood leaves, whereas, they tended to increase slightly in yaupon and honeysuckle tissues probably resulting from the growth of new leaves during winter warming trends.

\section{Cell-wall Constituents}

While assimilation of the highly digestible cell solubles was inhibited by shade, the poorly digestible cell-wall constituents (CWC), i.e., total fiber fraction of leaves, increased throughout the year with increasing shade. McEwen and Dietz (1965), Halls and Epps (1969), and Wolters (1973) found that crude fiber was higher in shaded vegetation than in open-grown forage. However, in contrast, Vallentine and Young (1959) and Wolters (1974) reported crude fiber lower in shaded herbaceous plants.

\section{Acid-detergent Fiber}

The ADF or lignocellulose fraction, which consists of cellulose, lignin, cutin, and acid-insoluble ash (mainly silica), was significantly increased in leave tissues of all species by shading (Table 1). Averaged over all months, the lignocellulose fraction was $23 \%$ higher in leaves under moderate shade and 54\% higher in those under deep shade than in open-grown tissues.

The ADF fraction was lowest in April and May tissues, increasing significantly in all species by mid-June. Few changes occurred during the remainder of the year. However, in dogwood leaves the ADF fraction increased substantially as leaves abscised in late autumn. Also, ADF tended to decrease slightly in honeysuckle from late summer to winter, probably because of the addition of new winter leaves which were lower in fiber fractions.

\section{Hemicellulose and Cellulose}

Hemicellulose, composed of mixed polysaccharides, appeared to be influenced only by deep shade, this difference occurring only in leaf tissues of yaupon and honeysuckle (Table 1). In these species the hemicellulose fraction was significantly lower, throughout most of the year, in $92 \%$ shade than in $55 \%$ shade or full sunlight. In all months, dogwood leaves contained substantially lower levels of hemicellulose than leaves of other species.

Without exception, reduced light brought about higher levels of cellulose in all species throughout the year. Levels increased significantly as shade deepened. On the average there was $32 \%$ more cellulose in leaves grown under moderate shade and $70 \%$ more under deep shade than in leaves grown in full sunlight. Other than substantially higher levels in the abscised leaves of dogwood and a significant increase in maturing tissues from May to June, cellulose content varied little during the year.

\section{Acid-detergent Lignin}

Reduced solar radiation had little apparent influence on the ADL content of dogwood leaves at any time during the year (Table 1). Furthermore, dogwood leaves generally contained only onehalf to one-third the ADL content of either yaupon or honeysuckle. ADL content of yaupon and honeysuckle leaves was significantly higher in deep shade than in the open or under moderate shade. The difference noted between moderate shade and open sunlight was not significant.

In contrast to living leaves on the tree, abscised leaves of dogwood were substantially higher in ADL. Honeysuckle was lower in ADL in spring than during other months. Otherwise, nondigestible lignin varied little in leaf tissues throughout the year.

\section{Silica}

Silica was exceptionally low in leaves at all seasons, not exceeding about $1 \%$ of the dry matter. At such low concentrations, nondigestible silicates would probably have little impact on the metabolic value of leaf tissues (Goering and Van Soest 1970).

\section{Apparent Digestible Energy}

Differences in ADE among shade regimes, months, and species primarily reflected variations in dry-matter digestibility of leaves and not changes in the caloric content in tissues. In general, gross energy levels in leaves- were not affected by shade, nor did gross caloric contents vary significantly between species or months. Gross energy content over species and months averages 4719 cal $/ \mathrm{gm}$.

Shade did not influence ADE values of all species similarly. Dogwood leaves growing in the open and under $55 \%$ shade contained about the same level of ADE which was significantly higher than caloric values for leaves growing in deep shade (Table 1). Leaves in full sun or under moderate shade averaged $66 \%$ more ADE in spring than deep shaded tissues, $75 \%$ more in summer, and $36 \%$ more in winter.

ADE in yaupon and honeysuckle leaves declined significantly during all seasons as shade deepened. In spring, open-grown leaves were $20 \%$ higher in caloric value than those in moderate shade and $61 \%$ higher than those in deep shade. During summer the respective differences were $26 \%$ and $74 \%$; winter differences were $22 \%$ and $75 \%$.

Spring leaves of all species were seasonally highest in ADE. These values dropped significantly as leaves matured by mid-June and, except for a further decline in abscised dogwood leaves, changed little during summer through winter.

\section{In Vivo Dry-matter Digestlbility}

Shade tended to decrease the IVDMD of leaf tissues although the extent of this influence varied somewhat by species (Table 1). Dogwood leaves growing in full sun tended to be slightly more digestible than those under moderate shade. These leaves were significantly higher in digestibility at all months than leaves growing in deep shade. For example, the dry matter of dogwood leaves in full sun or under moderate shade was $68 \%$ more digestible than deep shaded leaves in spring, $71 \%$ more digestible in summer, and $24 \%$ more digestible in winter.

At all seasons, IVDMD of yaupon and honeysuckle leaves declined significantly with each increase in shade. Spring leaves in the open were $20 \%$ more digestible than those in moderate shade and $60 \%$ more digestible than those in deep shade. From summer through winter, dry-matter digestibility of open-grown tissues averages $25 \%$ higher than leaves in moderate shade and $70 \%$ higher than those in deep shade. For purposes of comparison, the IVDMD of leaves averaged $61 \%$ in full sun, $55 \%$ in moderate shade, and a low of only $37 \%$ in deep shade.

Rapidly growing spring leaves of all species were highest in metabolic usefulness; digestibility levels declined significantly with tissue maturation by mid-June. Little variation occurred from 
summer through winter, except that abscised leaves of dogwood declined rather sharply in digestibility.

In earlier research, Deinum et al. (1968) and Hight et al. (1968) found that shade ( 22 to $30 \%$ of full sunlight) significantly reduced dry matter intake as well as the digestibility of forage by sheep. They attributed the reduced intake of shaded forage to its lower soluble carbohydrate content in cell solubles.

\section{Discussion}

Results presented here and in supporting literature show that light has a substantial influence upon the nutritive value of forages for primary consumers such as deer and livestock. Animals are dependent upon photosynthetic activities within forage plants to synthesize nutrients essential for their growth, maintenance, and reproduction.

In this and other research, results have shown that high light intensities enhance some desirable nutrient relationships, while shade enhances other constituents that are also desirable and important from the standpoint of animal nutrition. For example, as the intensity of the light climate increased, the content of readily digestible and nutritious cell solubles increased in browse leaves while fibrous cell-wall fractions decreased. With increasing light, the level of digestible energy and the digestibility of leaf dry matter also increased. In contrast, protein, phosphorus, and calcium, nutrients equally essential to the growth and maintenance of herbivores, generally increased as light intensity declined. Unfortunately, however, shade also favored production of fiber fractions in leaf tissues and it is widely recognized that fibrous cell-wall constituents limit the metabolic usefulness of forages (Short and Regor 1970, Short et al. 1974). The inhibiting affect is not constant since nutritive availability of the cell-wall fraction varies among forages (Van Soest 1967).

The contrasting associations of essential nutrients from high to low levels of light confirm the need for additional study to determine the optimum range of light intensity that will seasonally provide the highest sustained production of nutrients. To aid in evaluating this question, digestion coeffecients of protein and other important constituents, including fiber fractions, should be determined for shade-grown leaves. Fiber hinders the action of digesting enzymes; hence, it tends to exert a protective influence against the digestibility of all nutrients (Maynard and Loosli 1969). This inhibition applies not only to the various plant parts, but it also applies to each cell with its fibrous membrane or cell wall. Therefore, it is conceivable that the relatively high fiber content associated with leaves grown in shade, especially those in heavy shade, might substantially reduce the digestibility or metabolic availability of the relatively high protein, phosphorus, and calcium fractions that appear to be prevalent in these tissues. If the reduction is sufficiently great, shaded tissues may provide little more digestible protein, phosphorus, and calcium than leaves in the open which appear to contain relatively lower levels of these constituents.

Considerable evidence suggests that light intensities in the medium to high range may provide the most productive light climate for palatable and nutritious browse leaves in a forest understory. Not only do these leaves appear to provide higher levels of soluble carbohydrates, digestible energy, and digestible dry matter in conjunction with relatively low fiber levels, as contrasted to leaves grown in heavy shade, but growth and production of leaf biomass also increases with increasing light (Blair 1969). With increased biomass, greater production of digestible nutrients, including protein, phosphorus, and calcium, might conceivably be achieved with moderate to high light intensities.

During late autumn and winter, leaves of broadleaf evergreens, growing under high levels of sunlight, would be particularly important contributors to the nutrition of herbivores because of the presence of relatively high levels of digestible energy. Leaves of deciduous species, on the other hand, generally lose most of their food value with abscission in late autumn (Blair et al. 1980, Short et al. 1975). From nutrition studies on forages, Swift (1957) con- cluded that if free-ranging deer are able to meet their needs for digestible energy, then requirements for protein and other nutrients probably will be covered incidentally.

Although leaf growth is reduced in heavier shade, the relatively high protein and mineral content associated with these tissues indicates that they are a potentially valuable food source in a forest habitat. Even in pine or pine-hardwood stands managed for high light transmission to the understory, numerous areas of relatively heavy shade will persist and support a limited growth of browse leaves.

\section{Literature Cited}

Association of Onincial Agricultural Chemists. 1965. Official Methods of Analysis 10th ed., Washington, D.C.

Blair, R.M. 1969. Timber stand density influences food and cover. p. 74-76. In: White-tailed deer in the southern forest habitat. Proc. Symp. Nacogdoches, Tex. USDA, Forest Serv., South. Forest Exp. Sta., New Orleans, La.

Blair, R.M., and L.K. Halls. 1968. Growth and forage quality of four southern browse species. Proc. Annu. Conf. Southeast. Assoc. Game and Fish Comm., 21:57-62.

Blair, R.M., and E.A. Epps, Jr. 1969. Seasonal distribution of nutrients in plants of seven browse species in Louisiana. USDA, Forest Serv. Res. Pap. SO-5I. South. Forest Exp. Sta., New Orleans, La.

Blair, R.M., H.L. Short, L.F. Burkart, A. Harrell, and J.B. Whelan. 1980. Seasonality of nutrient quality and digestibility of three southern deer browse species. USDA, Forest Serv. Res. Pap. SO-161. South Forest Exp. Sta., New Orleans, La.

Burton, G.W., J.E. Jackson, and F.E. Knox. 1959. The influence of light reduction upon the production, persistence and chemical composition of coastal bermudagrass, Cynodon dactylon. Agron. J. 51:537-542.

Carlile, D.W. 1978. The effects of forest thinning on the food-based carrying capacity of a mixed oak forest for white-tailed deer in the Ridge and Valley Province of Virginia. Unpublished Master thesis, V.P.I. and S.U., Blacksburg.

Cook, C.W., and L.E. Harris. 1950. The nutritive value of range forage as affected by vegetation type, site, and stage of maturity. Utah Agr. Exp. Sta. Bull. 344. Logan.

Deinum, B. 1966. Climate, nitrogen and grass. Research into the influence of light intensity, temperature, water supply and nitrogen on the production and chemical composition of grass. Meded. Landb., Wageningen, Nederland. 66(11).

Deinum, B., A.J.H. Van Es, and P.J. Van Soest. 1968. Climate, nitrogen and grass II. The influence of light intensity, temperature, and nitrogen on vivo digestibility of grass and the prediction of these effects on some chemical procedures. Netherlands J. Agr. Sci. 16:217-223.

Goering, H.K., and P.J. Van Soest. 1970. Forage fiber analyses (apparatus, reagents, procedures, and some applications). USDA, Agr. Res. Serv. Agr. Handb. No. 379.

Halls, L.K., and R. Alcaniz. 1965. Seasonal twig growth of southern browse plants. USDA, Forest Serv. Res. Note SO-23. South Forest Exp. Sta., New Orleans, La.

Halls, L.K., and E.A. Epps, Jr. 1969. Browse quality influenced by tree overstory in the South. J. Wildl. Manage. 33:1028-1031.

Harlow, R.F., and R.G. Hooper. 1972. Forages eaten by deer in the southeast. Proc. Annu. Conf. Southeast. Assoc. Game and Fish Comm. 25:1846.

Hight, G.K., D.P. Sinclair, and R.J. Lancaster. 1968. Some effects of shading and of nitrogen fertilizer on the chemical composition of freeze-dried and oven-dried herbage and on the nutritive value of oven-dried herbage fed to sheep. New Zealand J. Agr. Res. 11:286-302.

Kramer, P.J., and T.T. Kozlowski. 1979. Physiology of woody plants. Academic Press, N.Y.

Mayland, H.F., and D.L. Grunes. 1974. Shade-induced grass-tetany-prone chemical changes in Agropyron desertorum and Elymus cinereus. J. Range Manage. 27:198-201.

Maynard, L.A., and J.K. Loosli. 1969. Animal nutrition. McGraw-Hill Book Co., N.Y.

McEwen, L.C., and D.R. Dietz. 1965. Shade effects on chemical composition of herbage in the Black Hills. J. Range Manage. 18:184-190.

Myhr, K., and S. Saebo. 1969. The effects of shade on growth, development and chemical composition in some grass-species. Forsk. Fors. Landbr. 20:297-315.

Palmer, W.L., R.L. Cowan, and A.P. Ammann. 1976. Effect of inoculum source on in vitro digestion of deer foods. J. Wildl. Manage. 40:301-307. 
Robbins, C.T., P.J. Van Soest, W.W. Mautz, and A.N. Moen. 1975. Feed analyses and digestion with reference to white-tailed deer. J. Wildl. Manage. 39:67-79.

Short, H.L., R.M. Blair, and L. Burkart. 1972. Factors affecting nutritive values. p. 311-318. In: Wildland Shrubs-Their Biology and Utilization. USDA, Forest Serv. Gen. Tech. Rep. INT-1. Intermt. Forest and Range Exp. Sta., Ogden, Utah.

Short, H.L., R.M. Blair, and C.A.Segelquist. 1974. Fiber composition and forage digestibility by small ruminants. J. Wildl. Manage. 38:197-209.

Short, H.L., R.M. Blair, and E.A. Epps, Jr. 1975. Composition and digestibility of deer browse in southern forests. USDA, Forest Serv. Res. Pap. SO-111. South. Forest Exp. Sta., New Orleans, La.

Short, H.L., and J.C. Reagor. 1970. Cell wall digestibility affects forage value of woody twigs. J. Wildl. Manage. 34:964-967.
Swift, R.W. 1957. The nutritive evaluation of forages. Pennsylvania Agr. Exp. Sta. Bull. 615, Northeast Reg. Publ. 27. College of Agr. Pa. State Univ., Universty Park.

Tilley, J.M.A., and R.A. Terry. 1963. A two-stage technique for the in vitro digestion of forage crops. J. Brit. Grassland Soc. 18:104-111.

Vallentine, J.F., and V.A. Young. 1959. Factors affecting the chemical composition of range forage plants on the Edwards Plateau. Texas Agr. Exp. Sta. MP-384. College Station.

Van Soest, P.J. 1967. Development of a comprehensive system of feed analyses and its application to forages. J. Animal Sci. 26:119-128.

Wolters, G.L. 1973. Southern pine overstories influence herbage quality. J. Range Manage. 26:423-426.

Wolters, G.L. 1974. Longleaf uniola and spike uniola require shade. J. Range Manage. 27:45-47.

\section{To increase carrying capacity, improve forage quality and extend the pasture season, plant...}

\section{Perma-Pel Horse Pasture Seed Mix}

A special blend of tender, hardy grasses that are favored by horses and provide good protein forage and inexpensive TDN that saves on hay and grain costs. Grass seeds are selected for plants that grow good sod pastures, to reduce plant damage from trampling by horses with good pasture management. There are no clover seeds in this mix.

\section{Perma-Pel Cattle and Sheep Pasture Seed Mix}

A special blend with grasses, clovers and sub-clovers and other legume seeds to grow pastures that put efficient, economical weight gains on cattle and sheep. Special care is taken in this mix to add plants that reduce the danger of bloat, so long as a balanced grass population is maintained.
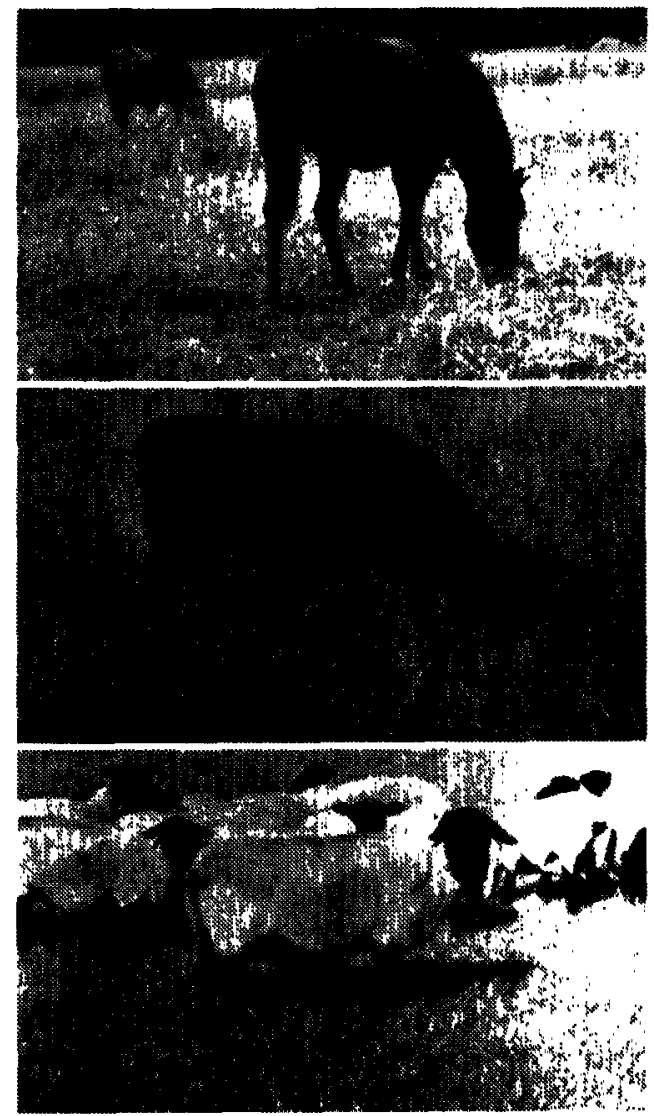

\section{One bag plants one acre.}

Perma-Pel Pasture

Seed Mixes are con-

veniently packaged

in bags designed for

planting one acre.

Both grass and

legume seeds are

coated with additives

that enhance the

microenvironment of

the soil surrounding the seed and

promote a high emergence rate. The

extra weight of this coating also anchors the seed to the ground and camouflages the seeds to prevent loss from birds while awaiting germination. All legume seeds are also coated with Rhizo-Kote to innoculate the seed with rhizobia (soil bacteria) to assure proper nitrogen fixation of the legume plants.

Look for this special Perma-Pel Pasture Seed Mix at your local seed dealer.

RANSEY SEED, INC. P.O. Box 352, Manteca, CA 95336 (209) 823-1721 